\title{
Comparison of the steroidogenic capacity of bovine follicular and luteal cells, and corpora lutea originating from dominant follicles of the first or second follicular wave
}

\author{
D. Wolfenson, H. Sonego, A. Shaham-Albalancy, Y. Shpirer and R. Meidan \\ Department of Animal Science, Faculty of Agriculture, Food and Environmental Quality Sciences, \\ The Hebrew University of Jerusalem, Rehovot 76100, Israel
}

\begin{abstract}
This study, compared the endocrine function of dominant follicles of the first and second follicular waves (DF1 and DF2, respectively) and the corpora lutea that were subsequently formed. In the experiments conducted in vitro, ovaries were collected from dairy cows on day $6.1 \pm 0.2$ or day $14.8 \pm 0.2$ of the oestrous cycle to obtain steroidogenically active DF1 $(n=8)$ and DF2 $(n=7)$. Granulosa and thecal cells were isolated, dispersed and incubated for $16 \mathrm{~h}$ with testosterone (granulosa cells) or forskolin or bLH (thecal cells). Both types of cell were subsequently cultured for 9 days with forskolin and insulin. The viability of the granulosa cells was similar in DF1 and DF2, but the concentration of oestradiol in the follicular fluid was higher in DF1 than in DF2. Production of oestradiol and progesterone by granulosa cells was similar in DF1 and DF2, but androstenedione and progesterone production by thecal cells were 3.5-6.5-fold higher in DF1 than in DF2. During the 9 days of luteinization, progesterone production was similar in DF1- and DF2-derived granulosa cells, but was two- to threefold higher in DF1- than in DF2-derived thecal cells. Experiments were also conducted in vivo. In Expt 1 in vivo, lactating cows that were assigned to ovulate DF1 or DF2 ( $n=9$ and 13 in replicate 1 and 2, respectively) were injected with $\mathrm{PGF}_{2 \alpha}$ on days 6 and 7 or on days 14 and 15 of the oestrous cycle, respectively. A wave by replicate interaction was detected for plasma progesterone concentration in the subsequent cycle: in the first replicate, progesterone production was approximately $40 \%$ higher in cows that ovulated DF1; in the second replicate, progesterone production was similar in cows that ovulated DF1 or DF2. In Expt 2, pooled plasma progesterone in the mid-luteal phase (days 12-15) after insemination of pregnant and non-pregnant cows was approximately $30 \%$ higher in cows that had ovulated DF1 $(n=32)$ than in cows that had ovulated DF2 $(n=22)$. This study showed DF1 had a higher steroidogenic capacity compared with DF2, which may be related to the hormonal environment in which the follicles developed.
\end{abstract}

\section{Introduction}

During the oestrous cycle in cattle, two or three follicular waves develop. A cohort of small follicles is recruited, of which a few continue to grow and one becomes the dominant follicle of the wave (Lucy et al., 1992; Savio et al., 1993). In heifers, patterns of three (Sirois and Fortune, 1988; Savio et al., 1988) or two follicular wave cycles (Knopf et al., 1989) have been reported. In matures cows, a two-wave cycle is predominant, and the dominant follicle of the second follicular wave (DF2) becomes a preovulatory follicle and ovulates. This was demonstrated in a large-scale study on mature lactating Holstein cows ( $n=131$; Bleach et al., 1998), indicating that $75 \%$ and $21 \%$ of the cows had two- and three-

Received 29 October 1998. wave cycles, respectively. A similar proportion of two- and three-wave cycles was observed in lactating Holstein cows (Roth, 1998) and Ahmad et al. (1997) reported that $86 \%$ and $14 \%$ of beef cows had two- and three-wave cycles, respectively. The dominant follicle of the first follicular wave (DF1) is a non-ovulatory follicle, because it develops during the first half of the oestrous cycle simultaneously with the corpus luteum. The time sequence of emergence, growth, selection, dominance and regression of DF1 is much more predictable than that of DF2. For this reason, and despite the fact that DF1 is not the ovulatory follicle, most studies of the biochemical and molecular parameters of follicular dynamics (Fortune, 1994; Tian et al., 1995; Xu et al., 1995a,b; Ginther $e$ al., 1996) have used DF1 rather than DF2.

Non-ovulatory DF1 and ovulatory DF2 develop in different endocrine environments. DF1 develops early in the oestrous cycle under low and increasing concentrations of Downloaded from Bioscientifica.com at 04/26/2023 10:13:34AM 
progesterone until days 5-6 of the oestrous cycle when it becomes maximally steroidogenic (Badinga et al., 1992). As progesterone secretion increases by day 8 of the oestrous cycle, the steroidogenic capacity of DF1 is decreased, and by day 12 it becomes atretic. DF1 ovulates only if the corpus luteum regresses. DF2 emerges on days 10-11 of the oestrous cycle and grows while plasma progesterone concentrations are high. The steroidogenic capacity of the two dominant follicles may therefore be different, and the corpora lutea produced after ovulation of DF1 or DF2 may have different characteristics.

In recent oestrous synchronization methods (Stevenson et al., 1996; Thatcher et al., 1996), a combination of GnRH and $\mathrm{PGF}_{2 \alpha}$ has been used to promote luteinization of large follicles, thereby allowing the growth of a new healthy ovulatory dominant follicle as a means of improving fertility (Coleman et al., 1991; Twagiramungu et al., 1992; Pursley et al., 1995; Schmidt et al., 1996). This approach reduced the interval from calving to conception, but conception rates per se were not improved. This finding may be explained by the fact that this approach does not take into consideration the origin (follicular wave) of the follicle or the endocrine environment (particularly progesterone concentration) in which the ovulatory follicle develops. An alternative approach for improving conception rates was examined in a fertility study in Holstein dairy cows (Shpirer and Wolfenson, 1997). A higher conception rate $(56 \%)$ was recorded in cows that ovulated DF1 (obtained by injection of $\mathrm{PGF}_{2 \alpha}$ on day 7 of the oestrous cycle) than in cows that ovulated DF2 (44\%; injection of $\mathrm{PGF}_{2 \alpha}$ on day 14) or in intact control cows $(45 \%)$. This finding indicates that, in cattle, there is a reproductive advantage in ovulating DF1 rather than DF2.

The aim of the present study was to compare the endocrine function of DF1 and DF2 and the corpora lutea that were subsequently formed. More specifically, follicular characteristics, steroid production of granulosa and thecal cells, progesterone production during in vitro luteinization of granulosa and thecal cells obtained from DF1 and DF2, and plasma progesterone curves during the oestrous cycle after. ovulation of either DF1 or DF2 were examined.

\section{Materials and Methods}

\section{In vitro production of steroids by granulosa and thecal cells and during luteinization}

Animals and experimental groups. The experiment was conducted during the winter, when mean daily maximal and minimal air temperatures were $18.6^{\circ} \mathrm{C}$ and $9.1^{\circ} \mathrm{C}$, respectively, and in accordance with Israeli legal requirements. Mature Holstein dairy cows showing regular oestrous cycles were used; the animals were in late lactation yielding $15-20 \mathrm{~kg}$ milk per day. Cows were fed a complete mixed ration containing $16.5 \%$ crude protein and $1.65 \mathrm{Mcal}$ $\mathrm{kg}^{-1}$ dry matter. For oestrous synchronization, a controlled intravaginal drug-releasing device (CIDR; Easy-Breed, AHI Plastics, Hamilton, New Zealand) was inserted for 9 days and $625 \mu \mathrm{g}$ Cloprostenol (a $\mathrm{PGF}_{2 \alpha}$ analogue; Estrumate,
Coopers, Berkhamsted) was injected i.m. 7 days after CIDR insertion. Cows that showed behavioural oestrus within $48 \mathrm{~h}$ after CIDR removal were included in the experiment. Before oestrous synchronization, the cows were assigned randomly to two groups: collection of ovaries on day 6 or day 15 of the oestrous cycle to obtain steroidogenically active DF1 and DF2. Cows assigned to be killed on day 15 were initiated into the synchronization procedure 9 days earlier than those in the other group to obtain DF1 and DF2 on the same day of development. Ovaries were collected within 20 min after the animals were killed and were kept on ice until dissection. The selection of days 6 and 15 for comparison of DF1 $(n=8)$ with DF2 ( $n=7)$ was on the basis of other studies describing follicular dynamics and development (Savio et al., 1988; Ginther et al., 1989; Sirios and Fortune, 1990; Wolfenson et al., 1995) and involved two criteria: (i) both DF1 and DF2 are at the growth phase of development on days 6 and 15, respectively, indicating that they are steroidogenically active; and (ii) from the day of emergence (that is, the day the dominant follicles were identified as approximately $4 \mathrm{~mm}$ in diameter, about day 1 and day 10 for DF1 and DF2, respectively) both types of follicle had grown for about 5 days until the actual experimental days: $6.1 \pm 0.2$ for DF1 and $14.8 \pm 0.2$ for DF2.

Tissue collection and cell incubation. On day 15 of the oestrous cycle, two large follicles were present in most animals: atretic DF1 and active DF2. Ultrasonography was not used in this study; DF2 was identified as the follicle with the greater number of viable granulosa cells and the higher oestradiol concentration in the follicular fluid. The oestradiol concentration was rapidly determined with an ${ }^{125} \mathrm{I}$-labelled oestradiol kit (Diagnostic Products, Los Angeles, CA; Meidan et al., 1990) during the separation and dispersion of granulosa and thecal cells for incubation. DF1 was easily identified because in most cases only one large follicle was present on day 6 of the oestrous cycle. However, when two large follicles were present (for example DF1 and one large atretic follicle from the previous cycle) a procedure similar to that described for DF2 was used to identify DF1.

The follicular diameter was measured during dissection and the follicular fluid was stored at $-20^{\circ} \mathrm{C}$ for steroid determination. Granulosa and thecal cells were isolated from the follicles, dispersed enzymatically and cultured as described by Meidan et al. (1990). After dispersion, granulosa and thecal cells were divided between short-term (h) and long-term (days) incubations. Briefly, the viability of granulosa and thecal cells was determined with Trypan blue. Viable cells of each type $\left(10^{5}\right)$ were incubated separately in a final volume of $0.5 \mathrm{ml}$ ( 24 wells per plate; Nunc, Kampstrup) in media (Dulbeco's modified Eagle's medium/Ham's nutrient mixture F-12 (1:1), Gibco, Grand Island, NY) containing $1 \%$ fetal calf serum (FCS; Biological Industries, Beit Haemek). Cells were incubated for $16 \mathrm{~h}$ at $37.5^{\circ} \mathrm{C}$ in $5 \%$ $\mathrm{CO}_{2}$ in basal media ( $1 \%$ FCS) with the addition of testosterone (300 $\mathrm{ng} \mathrm{ml}^{-1}$, Sigma, St Louis, MO) for granulosa cells, and forskolin (10 $\mathrm{mol} \mathrm{ml}^{-1}$, Sigma) or bovine LH (50 $\mathrm{ng} \mathrm{m}^{-1}$ bLH-B5, USDA, Animal Hormone Program, Beltsville MD) for thecal cells. For each treatment, four 
replicate wells were used. For the long-term incubation, $10^{5}$ granulosa cells and $3 \times 10^{4}$ thecal cells were cultured for 9 days in 1\% FCS medium containing forskolin and insulin (2 $\mu \mathrm{g} \mathrm{ml}^{-1}$, Sigma). Cells were washed and counted and fresh medium was added every $48 \mathrm{~h}$. Media were frozen and stored at $-20^{\circ} \mathrm{C}$ until assayed for steroid concentrations by radioimmunoassay.

\section{Plasma progesterone curves after ovulation of DF1 or DF2 in vivo}

Experiment 1. This experiment was performed in two replicates in the experimental herd of the Israeli Agricultural Research Organization during two consecutive winters. Cyclic cows in early lactation yielding on average $33.5 \mathrm{~kg}$ milk per day at approximately 50 days after calving were included. The oestrous cycle was synchronized as described for the in vitro experiments. After oestrus, cows assigned to ovulate DF1 or DF2 were injected twice with $\mathrm{PGF}_{2 \alpha^{\prime}}$ on days 6 and 7 , or on days 14 and 15 of the oestrous cycle, respectively. Previous studies indicated that in all cows injected with a luteolytic dose of $\mathrm{PGF}_{2 \alpha}$ as indicated above, the corpus luteum regressed and DF1 or DF2, respectively, was ovulated (Savio et al., 1990a; Wolfenson et al., 1995). Cows showing standing oestrus within $72 \mathrm{~h}$ of $\mathrm{PGF}_{2 \alpha}$ injection were included in the experiment. Jugular blood samples were collected into vacutainers every other day from day 1 to day 21 of the oestrous cycle. Plasma was separated and stored at $-20^{\circ} \mathrm{C}$ until assayed for progesterone. In replicates 1 and 2, four and five, and six and seven cows were included in the DF1 and DF2 groups, respectively.

Experiment 2. Blood samples collected from cyclic lactating Holstein dairy cows at approximately day 80 after calving and between day 12 and day 15 after insemination were assayed for plasma progesterone concentration. The two treatment groups consisted of cows that had previously ovulated DF1 after PGF $2 \alpha$ injection on day 7 of the oestrous cycle $(n=32)$ and those that had previously ovulated DF2 after $\mathrm{PGF}_{2 \alpha}$ injection on day 14 of the oestrous cycle $(n=22)$. In addition, each cow received a progesterone-containing CIDR on day 7 after insemination for 11 days, and an i.m. injection of Buserelin (10 $\mathrm{gg}$, Receptal, Hoechest, Frankfurt) on day 12 after insemination. On day 45 after insemination, cows were diagnosed for pregnancy by rectal palpation and designated as pregnant or non-pregnant.

\section{Determination of steroid concentrations}

Concentrations of oestradiol, androstenedione and progesterone in follicular fluid and media were determined by validated radioimmunoassays (Meidan et al., 1990; Wolfenson et al., 1997), using specific antibodies (Sigma). The sensitivities of the assays were 1.0,3.9 and $3.9 \mathrm{pg}$ per tube for oestradiol, androstenedione and progesterone, respectively. Intra- and interassay coefficients of variation were 9.9, 13.3 and $4.6 \%$, and $13.2,13.9$ and $8.6 \%$, for oestradiol, androstenedione and progesterone, respectively. The concentration of plasma progesterone was determined by a single solid-phase radioimmunoassay kit (P4-TG5, Diagnostic Products, Los Angeles, CA). The sensitivity of the assay was $0.2 \mathrm{ng} \mathrm{ml}^{-1}$, crossreaction with $20 \alpha$-dihydroprogesterone was $2.0 \%$ and with $\beta$-pregnan- $3 \alpha$-ol- 20 -one was $0.2 \%$. The intraassay coefficient of variation was $5 \%$.

\section{Statistical analysis}

Data were analysed by ANOVA using the general linear models procedure of the Statistical Analysis System (SAS, 1987). Data relating to follicular characteristics, and hormonal concentrations in the follicular fluid and media after short-term incubation, and to plasma progesterone concentration in Expt 2 in vivo were analysed by one-way ANOVA. Concentrations of steroid hormones in the media were expressed as ng per $10^{5}$ viable cells. Analyses were performed separately for basal and stimulated oestradiol and androstenedione production. The sources of variation in the mathematical model for progesterone production during luteinization include experimental groups (DF1 versus DF2), cows nested within groups, days of luteinization and days by groups interaction. For plasma progesterone concentration during the oestrous cycle in Expt 1 in vivo, the model includes experimental groups, experimental replicate, cows nested within group and replicate, days in the oestrous cycle and interactions.

\section{Results}

\section{Experiments in vitro}

Follicular characteristics and steroids in the follicular fluid. In the DF1 and DF2 groups, on days 6 or 15 of the oestrous cycle, one large healthy follicle was found in five cows and in one cow, respectively. Two large follicles, one atretic and one healthy, were found in three of eight and in six of seven cows in DF1 and DF2, respectively. Atretic follicles (not listed in Tables 1 and 2) were identified by a small number of viable granulosa cells and low oestradiol concentration in the follicular fluid. Follicular characteristics of DF1 and DF2, and

Table 1. Characteristics of dominant follicles of the first (DF1) and second (DF2) follicular waves in cows

\begin{tabular}{lcc}
\hline & DF1 & DF2 \\
\hline Number of animals & 7 & 8 \\
Day of oestrous cycle & $6.1 \pm 0.1$ & $14.8 \pm 0.2$ \\
Follicle diameter $(\mathrm{mm})$ & $11.6 \pm 0.7^{*}$ & $14.3 \pm 1.0$ \\
Total number of granulosa cells $\left(\times 10^{6}\right)$ & $2.7 \pm 0.7^{* *}$ & $4.7 \pm 0.8$ \\
Viability of granulosa cells $(\%)$ & $44.0 \pm 5.0$ & $45.0 \pm 4.0$ \\
Viability of thecal cells $(\%)$ & $>90$ & $>90$ \\
\hline
\end{tabular}

Values are mean $\pm \mathrm{SE}$.

Asterisks indicate significant differences between DF1 $(n=7)$ and DF2 $(n=8)$ : ${ }^{*} P<0.05,{ }^{*} P<0.07$. 
Table 2. Steroid concentrations in the follicular fluid of dominant follicles of the first (DF1) and second (DF2) follicular waves in cows

\begin{tabular}{lcc}
\hline & DF1 & DF2 \\
\hline Oestradiol $\left(\mathrm{ng} \mathrm{ml}^{-1}\right)$ & $152.0 \pm 21.0^{*}$ & $81.0 \pm 16.0$ \\
Androstenedione $\left(\mathrm{ng} \mathrm{m}^{-1}\right)$ & $8.3 \pm 3.1$ & $6.7 \pm 3.5$ \\
Progesterone $\left(\mathrm{ng} \mathrm{ml}^{-1}\right)$ & $15.3 \pm 2.0$ & $17.6 \pm 2.5$ \\
Ratio of oestradiol:androstenedione & 18.3 & 12.1 \\
Ratio of oestradiol:progesterone & 9.9 & 4.6 \\
\hline
\end{tabular}

Values for steroid concentrations are mean $\pm \mathrm{SE}$.

Asterisk indicates significant differences between DF1 $(n=7)$ and DF2 $(n=8)$ : ${ }^{*} P<0.05$.

steroid concentrations in the follicular fluid are presented (Tables 1 and 2, respectively). The diameter of DF1 was smaller $(P<0.02)$ than that of DF2 and the number of granulosa cells tended to be smaller $(P<0.07)$ in DF1 than in DF2; the viability of granulosa cells was similar in follicles of both groups. The concentration of oestradiol in the follicular fluid was higher $(P<0.02)$ in DF1 than in DF2. The viability of thecal cells was high $(>90 \%)$ in all cases. Androstenedione and progesterone concentrations in the follicular fluid were similar in follicles of both groups. The ratios of oestradiol: progesterone and oestradiol:andostenedione indicated that DF1 and DF2 were steroidogenically active. As expected, plasma progesterone concentration was higher $(6.8 \pm 0.7 \mathrm{ng}$ $\left.\mathrm{ml}^{-1} ; P<0.01\right)$ on day 15 than on day $6\left(3.4 \pm 0.4 \mathrm{ng} \mathrm{ml}^{-1}\right)$.

Steroid production by granulosa and thecal cells. There was no difference in basal production of oestradiol by granulosa cells in DF1 and DF2, or in the production of oestradiol in the presence of testosterone (Fig. 1a). Similarly, basal production of progesterone by granulosa cells did not differ among follicles in both groups (Fig. 1b). In contrast, in thecal cells, steroid production was dependent on the follicular wave from which the follicles were derived. LH- and forskolinstimulated androstenedione production (Fig. 2a) by thecal cells were 6.5- $(P<0.05)$ and tended to be 3.5-fold higher $(P<$ 0.10 ), respectively, in DF1 than in DF2. Basal production of androstenedione was higher in DF1 than in DF2, but the difference was not statistically significant. Production of progesterone by thecal cells was 4.5 -fold higher $(P<0.05)$ in DF1 than in DF2 (Fig. 2b).

Progesterone production during luteinization. During 9 days of luteinization in vitro, mean progesterone production ( $437 \pm 125$ versus $404 \pm 209 \mathrm{ng}$ per $10^{5}$ cells, respectively) as well as the shape and pattern of progesterone production curves were similar for DF1- and DF2-derived granulosa cells (Fig. 3a). In contrast, progesterone production by thecal cells from DF1 was higher than in those from DF2 (wave by day interaction; $P<0.05 ;$ Fig. $3 b$ ). Progesterone was two- to threefold higher on days 3-7 of luteinization in DF1 than in DF2; the difference decreased on day 9 of culture. Mean progesterone production rates by thecal cells from DF1 and DF2 were $264 \pm 70$ and $143 \pm 76$ ng per $10^{5}$ cells, respectively.
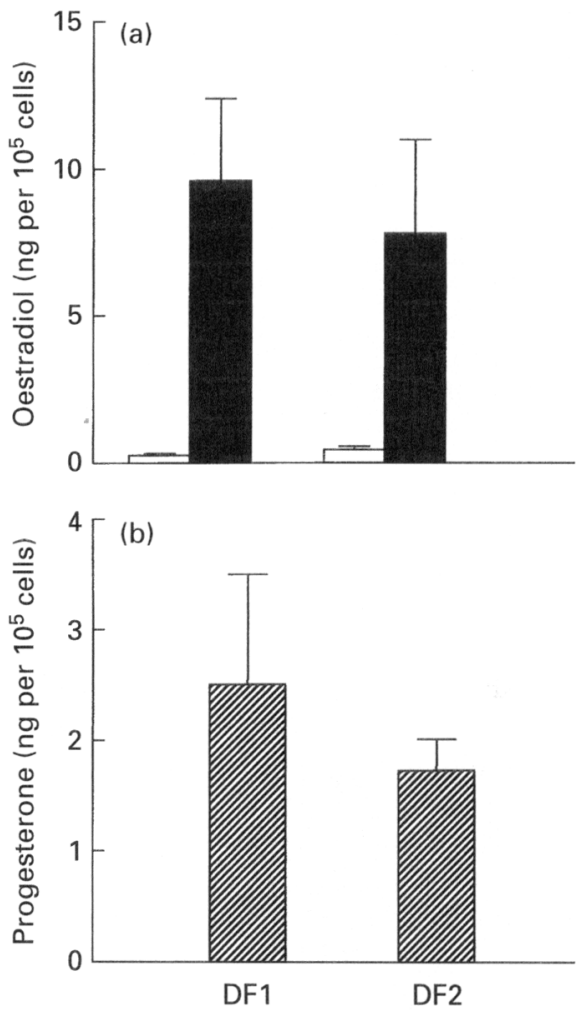

Fig. 1. (a) Production of oestradiol in the absence ( $\square$; basal value) or presence $(\boldsymbol{\square})$ of testosterone ( $\left.300 \mathrm{ng} \mathrm{m}^{-1}\right)$ and (b) basal production of progesterone (四) by bovine granulosa cells derived from dominant follicles of the first (DF1; $n=7$ ) and second (DF2; $n=8$ ) follicular waves, and cultured for $16 \mathrm{~h}$.

\section{Experiments in vivo}

Experiment 1. After ovulation of DF1 and DF2, plasma progesterone concentration curves during the subsequent cycles were examined in two replicates. A wave by replicate interaction was detected $(P<0.05)$. In the first replicate, mean plasma progesterone concentration during the oestrous cycle was higher after ovulation of DF1 than of DF2 ( $2.5 \pm 0.2$ and $1.8 \pm 0.2 \mathrm{ng} \mathrm{ml}^{-1}$, respectively, $P<0.03$; Fig. $4 \mathrm{a}$ ). Mean peak progesterone values during the luteal phase (days 13-17) were higher in DF1 than in DF2 groups (4.4 versus $3.2 \mathrm{ng} \mathrm{ml}^{-1}$, respectively, $\left.P<0.05\right)$. In contrast, in the second replicate no significant difference was observed between mean plasma progesterone concentration during the oestrous cycle after ovulation of DF1 or DF2 $(3.4 \pm 0.16$ and $3.8 \pm 0.16 \mathrm{ng} \mathrm{ml}^{-1}$, respectively; Fig. $4 \mathrm{~b}$ ). The curves were similar, but progesterone concentration during the luteal phase tended to be higher in cows that ovulated DF2 than in cows that ovulated DF1 (Fig. 4b). The duration of the oestrous cycle was similar in replicates 1 and 2 (22.8 \pm 0.5 and $22.5 \pm 0.5$ days, respectively).

Experiment 2. Mean plasma progesterone concentrations in the mid-luteal phase after insemination (days 12-15) of cows ovulating DF1 were higher than in cows ovulating DF2 (Table 3). Pooled progesterone concentration of pregnant and non-pregnant cows ovulating DF1 was about 30\% higher than that of cows ovulating DF2 (Table $3 ; P<0.01$ ).

Downloaded from Bioscientifica.com at 04/26/2023 10:13:34AM 
Table 3. Plasma progesterone concentration $\left(\mathrm{ng} \mathrm{ml}^{-1}\right)$ in the mid-luteal phase after insemination of cows ovulating the dominant follicle of the first (DF1) or second (DF2) follicular wave

\begin{tabular}{lcc}
\hline & DF1 & DF2 \\
\hline Number of animals & \multicolumn{1}{c}{32} & 22 \\
Pregnant & $4.70 \pm 0.34$ & $3.88 \pm 0.31$ \\
Non-pregnant & $4.72 \pm 0.49$ & $3.48 \pm 0.32$ \\
Overall mean (pregnant + non-pregnant) & $4.71 \pm 0.27^{*}$ & $3.70 \pm 0.22^{*}$ \\
\hline
\end{tabular}

Values are mean \pm SE.

Asterisks indicate significant differences between DF1 and DF2: ${ }^{*}<<0.05$.
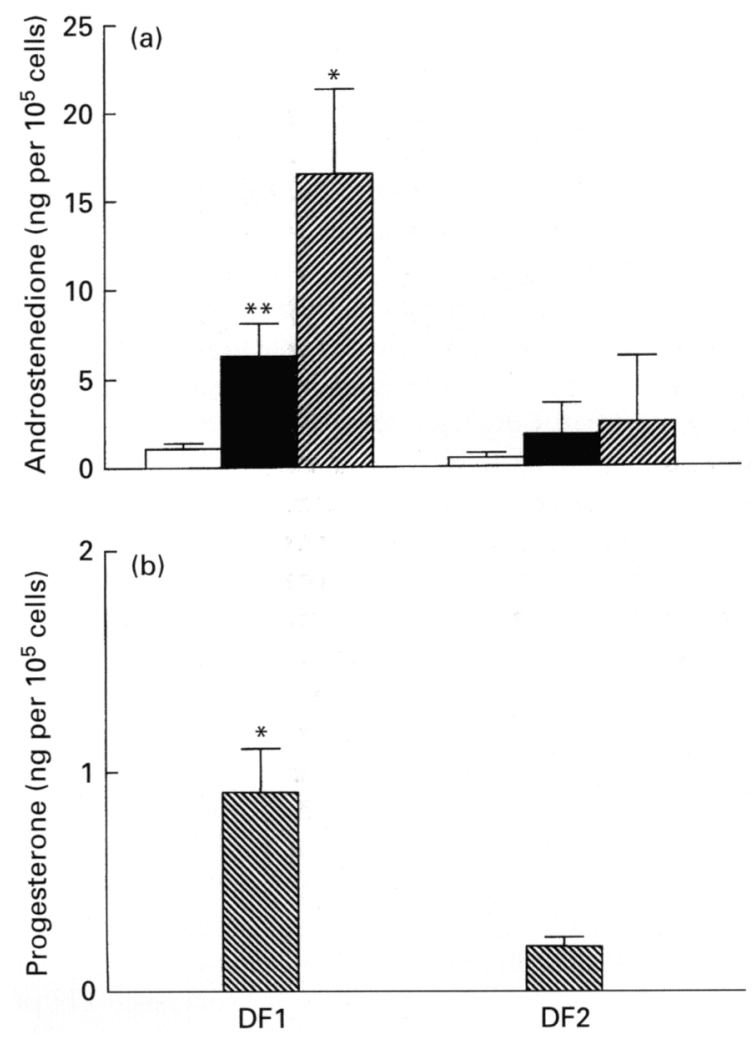

Fig. 2. (a) Basal $(\square)$, forskolin-stimulated $\left(10 \mu \mathrm{mol} \mathrm{l}^{-1} ; \mathbf{\square}\right)$ and LHstimulated (50 $\mathrm{ng} \mathrm{ml}^{-1}$; production of androstenedione and (b) basal production of progesterone $(\mathbb{\mathbb { N }})$ by bovine thecal cells derived from the dominant follicle of the first (DF1, $n=7$ ) or second (DF2, $n=8$ ) follicular wave and cultured for $16 \mathrm{~h}$. Asterisks indicate significant differences between DF1 and DF2, $* P<0.05$; and a tendency for significance $^{* *} P<0.1$.

\section{Discussion}

DF1 on day 6 and DF2 on day 15 were considered to be similar for the following reasons: (i) both DF1 and DF2 were allowed to develop for 5 days after emergence; (b) both DF1 and DF2 were examined in the growth phase (Wolfenson et al., 1995) while they were healthy and active (Ginther et al., 1989; Fortune, 1994); (iii) both DF1 and DF2 were steroidogenically active, as indicated by the fact that the ratios of oestradiol:progesterone and oestradiol:androstenedione

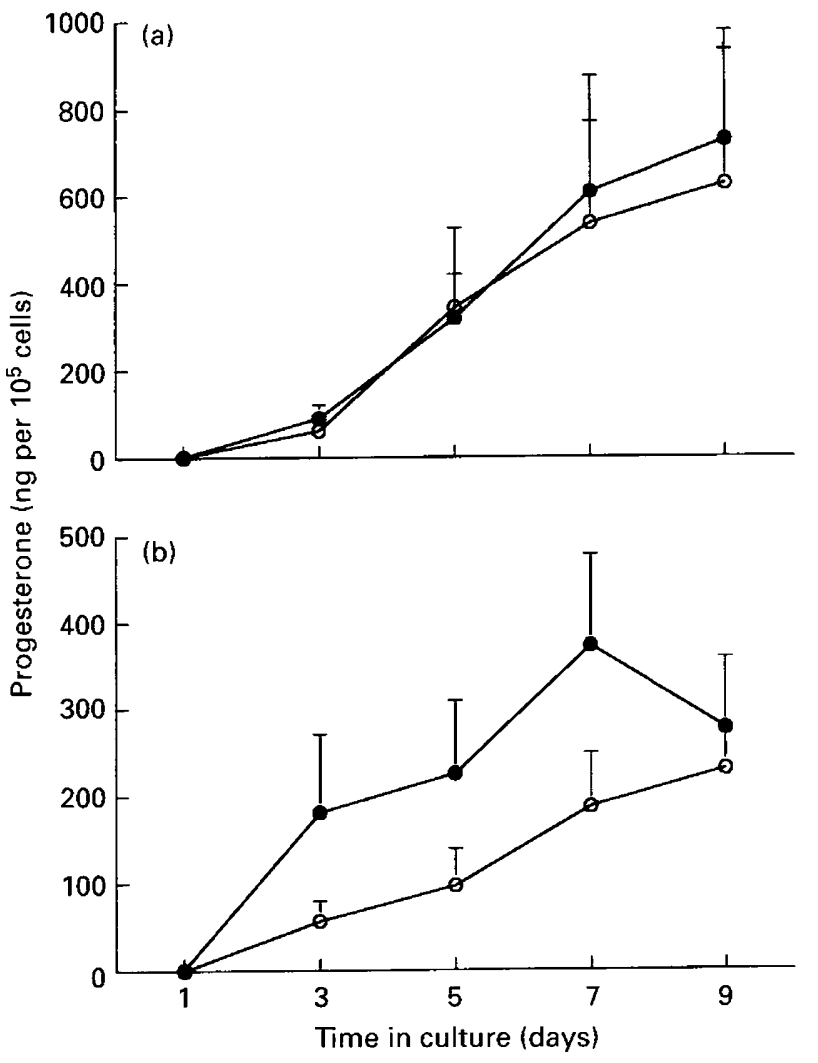

Fig. 3. Progesterone production by luteinized bovine (a) granulosa and (b) thecal cells derived from the dominant follicle of the first ( $n=7$ ) or second $(0, n=8)$ follicular wave and cultured for 9 days.

were $>1$, as well as by the absolute values of oestradiol, progesterone and androstenedione in the follicular fluid, which were within the range for steroidogenically active dominant follicles (Guilbault et al., 1993; Tian et al., 1995); and (iv) the viability of granulosa and thecal cells was similar in both types of follicle.

However, concurrent with these similarities, this study also highlighted differences between DF1 and DF2. The DF1derived thecal cells and luteinized thecal cells were steroidogenically more active than those derived from DF2. Potential in vivo implications of these differences were indicated by two of three experiments in which plasma progesterone curves were higher after ovulation of DF1 than DF2. However, the difference in steroid production may be limited to thecal cells, since DF1-derived granulosa cells and luteinized granulosa cells did not differ in steroid production from those derived from DF2.

The lower steroidogenic capacity of thecal cells from DF2 is unlikely to be related to the fact that DF2 is larger than DF1 because the size of the dominant preovulatory follicle is variable, ranging from 11 to $16 \mathrm{~mm}$ at oestrus (Quirk and Fortune, 1986). On the basis of this observation, Fortune $e t$ al. (1991) concluded that the size of the dominant follicle is not a reliable indicator of its functional status. Furthermore, depression of dominance in stressed cows is reflected in alterations of wave emergence or in the rate of decrease of the number of follicles of medium size, but not in the size of 

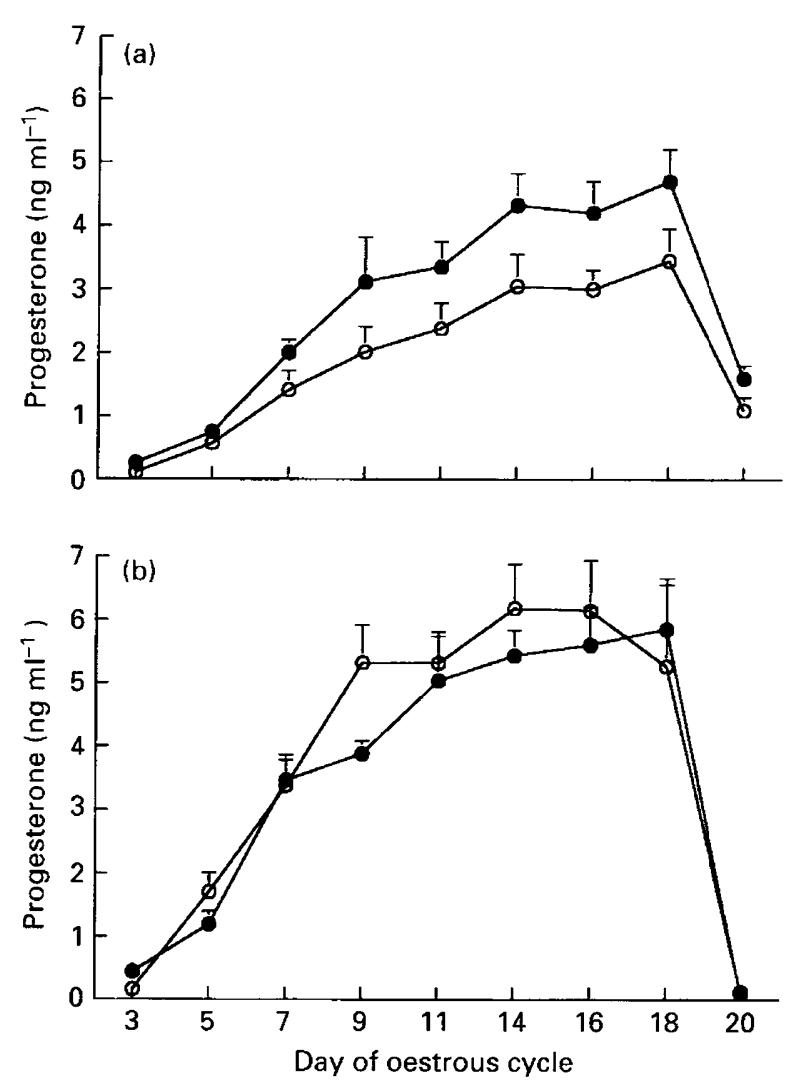

Fig. 4. Plasma progesterone concentrations in (a) replicate 1 and (b) replicate 2 of cows ovulating the dominant follicle of the first $(O)$ or second $(O)$ follicular wave. There was a significant difference $(P<$ 0.05 ) between the two groups of cows in plasma progesterone concentration during the oestrous cycle in replicate 1 , but not in replicate 2 .

the dominant follicle (Wolfenson et al., 1995). In addition, maximal steroidogenic capacity of a dominant follicle does not coincide with its maximal size (Badinga et al., 1992; Xu et al., 1995a,b).

LH-induced androstenedione production by thecal cells was greater in DF1- than in DF2-derived cells (15- versus fivefold, relative to basal production, respectively). Forskolin-induced androstenedione production (by direct stimulation of adenylyl cyclase) was also greater in thecal cells derived from DF1 than from DF2. The difference in androstenedione production between the DF1- and DF2derived cells was greater after stimulation with LH than forskolin. These findings indicate that the difference in the activity of thecal cells between the two follicles is primarily due to differences in the expression of $\mathrm{LH}$ receptors and binding of LH to its receptor. It is possible that intracellular activation of adenylate cyclase is also higher in thecal cells from DF1 than from DF2. Difficulties in detecting an increase in plasma oestradiol concentration during the emergence of the second follicular wave have been reported, whereas an increase in plasma oestradiol can be detected during the emergence of the first follicular wave (Savio et al., 1990b; Wolfenson et al., 1995). This may be related to low and high androgen production by DF2- and DF1-derived thecal cells, respectively, as reported in the present study.
A low plasma progesterone concentration during early stages of the oestrous cycle, when DF1 develops, results in an increase in LH pulse frequency. This increase stimulates androstenedione production by thecal cells (Sirois and Fortune, 1990; Savio et al., 1993; Fortune, 1994; Magoffin and Wietsman, 1994; Kinder et al., 1996). In the present study, the increased production of androgen by thecal cells was observed but not of oestradiol by granulosa cells. These findings are in agreement with a study by Tian et al. (1995), which demonstrated that during transition of dominant follicles to the preovulatory stage (when plasma progesterone decreases), the increase in oestradiol in the follicular fluid was associated with an increase in mRNAs for steroidogenic enzymes that participate in androstenedione production by thecal cells but not in aromatase activity in granulosa cells.

The present study showed that the origin of the dominant follicle (first or second wave) had an effect on the steroidogenic capacity of the thecal cell-derived luteal cells, as indicated by the higher progesterone production by DF1derived luteinized thecal cells. No such effect was observed in the luteinized granulosa cells, which produced similar amounts of progesterone regardless of their origin. It is possible that the exposure of DF1 to high LH concentrations early in development (days 2-6 of the oestrous cycle) alters its function at a later stage during luteinization, perhaps via an increased sensitivity of luteinized thecal cells to factors that stimulate cAMP production. Therefore, differences in plasma progesterone concentrations after ovulation of DF1 or DF2 may be related to progesterone produced by the luteinized thecal cells and not that produced by the luteinized granulosa cells. The fact that plasma progesterone concentration after ovulation of DF1 is not more than $1.5 \mathrm{ng} \mathrm{ml}^{-1}$ higher than after ovulation of DF2 may be due to the relatively small contribution (about $20 \%$ ) of the thecal-derived luteal cells to the progesterone produced by the corpus luteum (Niswender et al., 1985). Progesterone production (during luteinization) of cells derived from dominant follicles during the luteal phase in the present study was similar to that reported in cells derived from preovulatory dominant follicles in the study of Meidan et al. (1990). The pattern of progesterone production was similar despite the fact that the follicles obtained during the luteal phase were not exposed to the increased LH pulse frequency of the follicular phase. The presence of high concentrations of forskolin (a cAMP activator) in the culture media probably compensated for this.

In one of the two replicates of Expt 1, as well as in Expt 2, plasma progesterone concentration during the luteal phase was higher after ovulation of DF1 than DF2. The reason for the difference between the two replicates of Expt 1 is unclear: both replicates were performed on the same farm, during the winter and using similar management and nutrition. The difference may be related to plasma progesterone concentrations in the luteal phase: these were low in replicate 1 of Expt 1 and in Expt 2 , in which similar results were obtained (mean mid-luteal values of plasma progesterone about $3.8 \mathrm{ng} \mathrm{ml}^{-1}$ ) and high in replicate 2 of Expt 1 (about $5.6 \mathrm{ng} \mathrm{ml}^{-1}$ ). The higher fertility of cows inseminated after ovulation of DF1 compared with DF2 (Shpirer and Wolfenson, 1997) indicates indirectly a beneficial effect of the higher steroidogenic capacity of DF1 and the corpus luteum originating from it. 
In conclusion, this study compared steroid production and follicular characteristics of DF1 and DF2 and the corpora lutea that were subsequently formed. The results indicate that DF1 has a higher steroidogenic capacity than DF2 on the basis of four criteria: (i) a higher concentration of oestradiol in the follicular fluid; (ii) a higher production of androgen by thecal cells; (iii) a higher production of progesterone in vitro by luteinized thecal cells; and (iv) a higher plasma progesterone concentration in two of three experiments. This study indicates that the hormonal environment in which the follicle completes its development, becomes dominant and potentially ovulates is important for the acquisition of maximal steroidogenic capacity. Insemination after induction of ovulation of DF1 may improve fertility in cattle.

The authors wish to thank Y. Graber for technical help and A. Berman for his critical evaluation of the manuscript. This research was supported by research grant award No. IS-2297-93C from BARD, The US-Israel Binational Agricultural Research and Development Fund.

\section{References}

Ahmad N, Townsend EC, Dailey RA and Inskeep EK (1997) Relationships of hormonal patterns and fertility to occurrence of two or three waves of ovarian follicles before and after breeding in beef cows and heifers Animal Reproduction Science 49 13-28

Badinga L, Driancourt MA, Savio JD, Wolfenson D, Drost M, De la Sota RL and Thatcher WW (1992) Endocrine and ovarian responses associated with the first-wave dominant follicle in cattle Biology of Reproduction 47 871-883

Bleach ECL, Glencross RG and Knight PG (1998) Associations between ovulatory follicle development and pregnancy rates in spontaneously cycling dairy cows Journal of Reproduction and Fertility Abstract Series 22 Abstract 30

Coleman DA, Bartol FF, Spencer TE, Floyd JG, Wolfe DF and Brendemuehl JP (1991) Effect of potent GnRH-agonist on hormonal profiles, synchronization of oestrus and fertility in beef cattle Journal of Animal Science 69 Supplement 1396 (Abstract)

Fortune JE (1994) Ovarian follicular growth and development in mammals Biology of Reproduction 50 225-232

Fortune JE, Sirois J, Turzillo AM and Lavoir M (1991) Follicle selection in domestic ruminants Journal of Reproduction and Fertility Suppiement $\mathbf{4 3}$ 187-198

Ginther OJ, Kastelic JP and Knopf L (1989) Composition and characteristics of follicular waves during the bovine oestrous cycle Animal Reproduction Science $20187-200$

Ginther OJ, Wiltbank MC, Fricke PM, Gibbons JR and Kot K (1996) Selection of the dominant follicle in cattle Biology of Reproduction 55 1187-1194

Guilbault LA, Roullier P, Matton P, Glencross RG, Beard AJ and Knight PG (1993) Relationships between the level of atresia and inhibin contents ( $\alpha$ subunit and its dimer) in morphologically dominant follicles during their growing and regressing phases of development in cattle Biology of Reproduction 48 268-276

Kinder JE, Kojima FN, Bergfeld EG, Wehrman ME and Fike KE (1996) Progestin and estrogen regulation of pulsatile $\mathrm{LH}$ release and development of persistent ovarian follicles in cattle Journal of Animal Science 74 1424-1440

Knopf L, Kastelic JP, Schallenberger E and Ginther OJ (1989) Ovarian follicular dynamics in heifers: test of two-wave hypothesis by ultrasonically monitoring individual follicles Domestic Animal Endocrinology 6 111-119

Lucy MC, Savio JD, Badinga L, De la Sota RL and Thatcher WW (1992) Factors that affect ovarian follicular dynamics in cattle Journal of Animal Science $703615-3626$

Magoffin DA and Wietsman SR (1994) Insulin-like growth factor-I regulation of luteinizing hormone (LH) receptor messenger ribonucleic acid expression and LH-stimulated signal transduction in rat ovarian thecainterstitial cells Biology of Reproduction 51 766-775

Meidan R, Girsh E, Blum O and Aberdam E (1990) In vitro differentiation of bovine theca and granulosa cells into small and large luteal-like cells: morphological and functional characteristics Biology of Reproduction 43 913-921

Niswender GD, Schwall RH, Fitz TA, Farin CE and Sawyer HR (1985) Regulation of luteal function in domestic ruminants: new concepts Recent Progress in Hormone Research 41 101-151

Pursley JR, Mee MO and Wiltbank MC (1995) Synchronization of ovulation in dairy cows using $\mathrm{PGF}_{2 \alpha}$ and GnRH Theriogenology 44 915-923

Quirk SM and Fortune JE (1986) Plasma concentrations of gonadotrophins, preovulatory follicular development and luteal function associated with bovine follicular fluid induced delay of oestrus in heifers fournal of Reproduction and Fertility 76 609-621

Roth $\mathbf{Z}(1998)$ Immediate and Delayed Effect of Heat Stress on Ovarian Follicular Development and Function in Dairy Cows MSc Thesis, submitted to the Faculty of Agriculture, The Hebrew University of Jerusalem, Israel

SAS (1987) SAS User's Guide SAS Institute, Cary, NC

Savio JD, Keenan L, Boland MP and Roche JF (1988) Pattern of growth of dominant follicles during the oestrous cycle of heifers Journal of Reproduction and Fertility 83 663-671

Savio JD, Boland MP, Hynes N and Mattiacci MR (1990a) Will the first dominant follicle of the oestrous cycle of heifers ovulate following luteolysis on day 7? Theriogenology $33677-687$

Savio JD, Thatcher WW, Badinga L, De-la Sota RL and Wolfenson D (1993) Regulation of dominant follicle turnover during the oestrous cycle in cows Journal of Reproduction and Fertility 97 197-203

Savio JD, Boland MP and Roch JF (1990b) Development of dominant follicle and length of ovarian cycles in post-partum dairy cows fournal of Reproduction and Fertility 88 581-591

Schmidt EJ-P, Diaz TC, Drost M and Thatcher WW (1996) Use of a gonadotropin-releasing hormone agonist or human chorionic gonadotropin for timed insemination in cattle Journal of Animal Science 74 1084-1091

Shpirer Y and Wolfenson D (1997) Combined hormonal treatment for improvement of fertility of dairy cows 9 th Annual Meeting of the Israeli Dairy Production Conference p. 25 Israel Cattle Breeders Association, Caesaria, Israel (in Hebrew)

Sirois J and Fortune JE (1988) Ovarian follicular dynamics during the estrous cycle monitored by real-time ultrasonography Biology of Reproduction 39 308-317

Sirois J and Fortune JE (1990) Lengthening the bovine oestrous cycle with low levels of exogenous progesterone: a model for studying ovarian follicular dominance Endocrinology 127 916-925

Stevenson JS, Kobayashi Y, Shipka MP and Rouchholz KC (1996) Altering conception of dairy cattle by gonadotropin-releasing hormone preceding luteolysis induced by prostaglandin $F_{2 \alpha}$ Journal of Dairy Science 79 402-410

Thatcher WW, De La Sota RL, Schmidt EJ-P, Diaz TC, Badinga L, Simmen FA, Staples CR and Drost M (1996) Control and management of ovarian follicles in cattle to optimize fertility Reproduction Fertility and Development 8 203-217

Tian XC, Berndtson AK and Fortune JE (1995) Differentiation of bovine preovulatory follicles during the follicular phase is associated with increases in messenger ribonucleic acid for cytochrome P450 side chain cleavage $3 \beta$ hydroxysteroid dehydrogenase and $\mathrm{p} 45017 \alpha$ hydroxylase but not P450 aromatase Endocrinology 136 5102-5110

Twagiramungu H, Guilbault LA, Proulx J, Villeneuve P and Dufour JJ (1992) Influence of an agonist of gonadotropin-releasing hormone (buserelin) on oestrus synchronization and fertility in beef cattle Journal of Animal Science 70 1904-1910

Wolfenson D, Thatcher WW, Badinga L, Savio JD, Meidan R, Lew BJ, BrawTal R and Berman A (1995) Effect of heat stress on follicular development during the oestrous cycle in lactating dairy cows Biology of Reproduction $\mathbf{5 2}$ 1106-1113

Wolfenson D, Lew BJ, Thatcher WW, Graber Y and Meidan R (1997) Seasonal and acute heat stress effects on steroid production by dominant follicles in cows Animal Reproduction Science 47 9-19

Xu Z, Garverick HA, Smith GW, Smith MF, Hamilton SA and Youngquist RS (1995a) Expression of messenger ribonucleic acid encoding cytochrome P450 side-chain cleavage, cytochrome P450 17a-hydroxylase, and cytochrome P450 aromatase in bovine follicles during the first follicular wave Endocrinology 136 981-989

Xu Z, Garverick HA, Smith GW, Smith MF, Hamilton SA and Youngquist RS (1995b) Expression of follicle stimulating hormone and luteinizing hormone receptor messenger ribonucleic acids in bovine follicles during the first follicular wave Biology of Reproduction 53 951-957 